\title{
CITRA MEREK, HARGA, DAN KEMASAN BERDAMPAK TERHADAP KEPUTUSAN PEMBELIAN KONSUMEN
}

\author{
William Devrillio Lay \\ Jurusan Internasional Bisnis Manajemen Universitas Ciputra \\ wdevrillio@student.ciputra.ac.id \\ Tina Melinda \\ Jurusan Internasional Bisnis Manajemen Universitas Ciputra \\ tina.melinda@ciputra.ac.id
}

\begin{abstract}
ABSTRAK
Tujuan penelitian ini adalah untuk mengetahui pengaruh variabel citra merek, harga, dan kemasan terhadap keputusan pembelian konsumen Nexfood. Jumlah populasi yang digunakan adalah 108 orang yang merupakan konsumen Nexfood. Jumlah sampel yang digunakan adalah 40 orang yang semuanya merupakan konsumen Nexfood. Variabel yang diteliti dalam penelitian ini adalah citra merek (X1), Harga (X2), kemasan (X3), dan keputusan pembelian (Y). Teknik pengambilan sampel dalam penelitian ini menggunakan metode purposive sampling. Teknik analisis yang digunakan dalam penelitian ini adalah teknik analisis regresi linier berganda. Hasil penelitian menunjukan bahwa citra merek, harga, dan kemasan berpengaruh terhadap keputusan pembelian di Nexfood.
\end{abstract}

Kata kunci:

Citra merek, Harga, Kemasan, Keputusan Pembelian

\begin{abstract}
The purpose of this research is to determine the effect of brands, prices, and packaging on Nexfood consumer purchasing decisions. The population used is 108 people from consumers of Nexfood. The number of samples used for this research is 40 people from Nexfood consumers. The variables in this research are brand image (X1), Price (X2), packaging (X3), and purchase decision (Y). The sampling technique in this study used a purposive sampling method. The analysis technique used in this study is multiple linear regression analysis techniques. The results of this research shown that brand image, price, and packaging have an effect on purchases decisions at Nexfood products.
\end{abstract}

Keywords:

Brand image, price, packaging, purchase decisions 


\section{PENDAHULUAN}

Perkembangan industri makanan di Indonesia berkembang dengan sangat baik sehingga sangat menjanjikan dan begitu diminati oleh masyarakat Indonesia. Peluang untuk membuat bisnis di bidang makanan dan minuman akan bagus karena menunjukkan bahwa permintaan masyarakat terhadap produk makanan dan minuman sangat tinggi. Tetapi di tengah tingginya permintaan masyarakat, Nexfood selaku perusahaan yang bergerak di bidang makanan dan minuman mengalami penurunan penjualan. Hal ini membuat Nexfood harus dapat memperbaiki diri agar penjualan dapat meningkat dan mengungguli para pesaing.

Faktor citra merek, harga, dan kemasan merupakan faktor yang akan dipertimbangkan konsumen dalam memutuskan pembeliannya menurut hasil pra survey yang telah dilakukan. Penelitian ini bertujuan untuk mengetahui pengaruh yang ditunjukkan oleh variabel citra merek, harga, dan kemasan terhadap keputusan pembelian konsumen.

\section{TINJAUANN TEORI DAN}

\section{PENGEMBANGAN HIPOTESIS}

\section{Citra Merek}

Menurut Tjiptono (2015), suatu hal yang dicerminkan di dalam suatu asosiasi atau di ingatan mengenai suatu pengamatan juga kepercayaan terhadap suatu merek. Yustiawan (2016) mengatakan bahwa lambang, warna, desain tampilan atau semua yang terkandung dan menjadi bagian dalam suatu merek dapat dikatakan sebagai definisi dari citra merek. Menurut Monawarah (2017), indikator merek adalah merek yang dapat diingat, merek yang disukai, dan yang terakhir merek yang dapat diadaptasi.

\section{Harga}

Tunis (2016) menyatakan bahwa harga adalah alat tukar yang berupa uang yang mampu menjadi alat penukaran untuk barang dan jasa. Menurut Tunis (2016), penetapan harga produk yang tepat adalah kunci suatu perusahaan agar sukses dalam memasarkan produknya kepada konsumen. Menurut Kotler dan Armstrong (2015) harga merupakan jumlah uang yang harus dikorbankan atau dibebankan untuk suatu nilai atau manfaat yang akan diterima oleh konsumen dalam bentuk produk atau jasa. Monawarah (2017) mengatakan terdapat tiga indikator dari 
harga yaitu keterjangkauan harga,

kesesuaian harga dengan kualitas produk,

kesesuaian harga dengan manfaat produk.

\section{Kemasan}

Setiawati (2017) kegiatan perancangan dan produksi wadah produk dapat disebut dengan kemasan. Resmi (2015) menjelaskan definisi kemasan sebagai suatu benda yang memiliki fungsi proteksi, menjaga keamanan pada suatu produk, dan meninggalkan suatu citra kepada konsumen yang telah memakainya. Menurut Resmi (2015) terdapat tiga fungsi sebuah kemasan yaitu dapat melindungi produk, memberikan kemudahan penggunaan produk, dan sebagai media program pemasaran perusahaan.

\section{METODE RISET}

\section{Metode Penelitian}

Jenis penelitian yang digunakan adalah penelitian dengan menggunakan metode penelitian kuantitatif. Penelitian kuantitatif sendiri memiliki arti yaitu penelitian yang berfokus pada suatu populasi atau sampel. Penggunaan instrumen penelitian dan analisis data yang memiliki sifat kuantitatif atau statistik merupakan kegiatan untuk menguji hipotesis yang telah ada (Sugiyono, 2014).

\section{Definisi Operasional}

Penelitian ini terdiri dari variabel independen dan variabel dependen. Variabel independen yaitu citra merek, harga, dan kemasan. Sedangkan untuk variabel dependen adalah keputusan pembelian. Keterangan variabel dan indikator penelitian ini tertera pada tabel 1 .

\section{Populasi dan Sampel}

Pada penelitian ini, populasi yang digunakan adalah seluruh konsumen yang pernah membeli produk Nexfood yaitu sebanyak 108 orang. Sampel akan diambil dengan menggunakan teknik purposive sampling dengan ciri - ciri responden yaitu berdomisili di Surabaya dan minimal sudah melakukan pembelian sebanyak 1 kali. Metode ini merupakan bagian dari non-probability sampling.

Menurut Roscoe dalam Sugiyono (2012), panduan untuk menentukan ukuran sampel yaitu ukuran sampel yang layak berkisar antara 30 sampai dengan 500 responden dan ukuran sampel minimal 10 kali dari jumlah variabel yang diteliti. Karena variabel yang diteliti ada 4, maka peneliti memutuskan untuk mengambil jumlah sampel dengan jumlah 40 orang. 
Tabel 1. Variabel dan Indikator

\begin{tabular}{|c|c|}
\hline Variabel & Indikator \\
\hline $\begin{array}{l}\text { Citra Merek (X1) } \\
\text { Tingkat persepsi } \\
\text { konsumen untuk } \\
\text { mengetahui seberapa } \\
\text { besar merek tersebut } \\
\text { tersimpan di memori } \\
\text { mereka, persepsi } \\
\text { tentang merek } \\
\text { tersebut didapat dari } \\
\text { hasil informasi dan } \\
\text { pengalaman } \\
\text { sebelumnya dari } \\
\text { merek tersebut. } \\
\text { (Sholicah, 2015) }\end{array}$ & $\begin{array}{l}\text { Indikator citra } \\
\text { merek menurut } \\
\text { Monawarah (2017) } \\
\text { adalah : } \\
\text { 1) Dapat diingat } \\
\text { 2) Disukai } \\
\text { 3) Dapat } \\
\text { diadaptasi }\end{array}$ \\
\hline $\begin{array}{l}\text { Harga (X2) } \\
\text { Persepsi konsumen } \\
\text { mengenai jumlah } \\
\text { uang yang } \\
\text { dikorbankan atau } \\
\text { dibebankan untuk } \\
\text { suatu nilai atau } \\
\text { manfaat yang akan } \\
\text { diterima oleh } \\
\text { konsumen dalam } \\
\text { bentuk produk atau } \\
\text { jasa. (Kotler dan } \\
\text { Armstrong, 2015) }\end{array}$ & $\begin{array}{l}\text { Indikator harga } \\
\text { menurut } \\
\text { Monawarah (2017) } \\
\text { adalah: } \\
\text { 1) Keterjangkauan } \\
\text { harga. } \\
\text { 2) Kesesuaian } \\
\text { harga dengan } \\
\text { kualitas } \\
\text { produk. } \\
\text { 3) Kesesuaian } \\
\text { harga dengan } \\
\text { manfaat. }\end{array}$ \\
\hline $\begin{array}{l}\text { Kemasan dapat } \\
\text { diartikan sebagai } \\
\text { suatu benda yang } \\
\text { berfungsi untuk } \\
\text { melindungi, } \\
\text { mengamankan } \\
\text { produk tertentu yang } \\
\text { berada di dalamnya } \\
\text { serta dapat } \\
\text { memberikan citra } \\
\text { tertentu pula untuk } \\
\text { membujuk } \\
\text { penggunanya } \\
\text { (Resmi, 2015). }\end{array}$ & 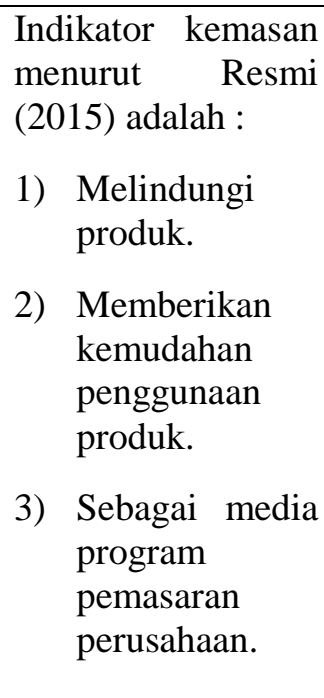 \\
\hline
\end{tabular}

\begin{tabular}{|c|c|}
\hline $\begin{array}{l}\text { Keputusan } \\
\text { Pembelian (Y) } \\
\text { Menurut Kotler dan } \\
\text { Keller (2016) } \\
\text { keputusan pembelian } \\
\text { adalah bentuk } \\
\text { pemilihan dan minat } \\
\text { untuk membeli } \\
\text { merek yang paling } \\
\text { disukai di antara } \\
\text { sejumlah merek yang } \\
\text { berbeda. }\end{array}$ & $\begin{array}{l}\text { Indikator } \\
\text { keputusan } \\
\text { pembelian menurut } \\
\text { Rohmah (2015) } \\
\text { adalah : } \\
\text { 1) Informasi } \\
\text { mengenai } \\
\text { produk. } \\
\text { 2) Kesesuaian } \\
\text { produk dengan } \\
\text { keinginan dan } \\
\text { kebutuhan. } \\
\text { 3) Loyalitas. } \\
\text { 4) Kemantapan } \\
\text { pada suatu } \\
\text { produk. }\end{array}$ \\
\hline
\end{tabular}

\section{HASIL PENELITIAN DAN PEMBAHASAN}

\section{Uji Validitas dan Reliabilitas}

Hasil pengujian validitas tertera pada Tabel 2 yang dilakukan terhadap setiap indikator variabel yang terdapat di penelitian ini. Diketahui bahwa hasil pengukuran validitas menunjukkan bahwa seluruh pernyataan yang digunakan pada keempat variabel penelitian memiliki tingkat signifikansi 0,000. Dengan demikian, dapat dikatakan bahwa instrumen pengukuran valid karena diketahui nilai signifikansi yang diperoleh adalah 0,000 atau kurang dari 0,05 (sig < 0,05). 
Tabel 2. Uji Validitas

\begin{tabular}{|l|l|l|l|}
\hline Variabel & $\begin{array}{l}\text { Pearson } \\
\text { Correlation }\end{array}$ & $\begin{array}{l}\text { Nilai } \\
\text { Sig. } \\
\text { tailed })\end{array}$ & Kesimpulan \\
\hline \multicolumn{5}{|l|}{ Citra Merek (X1) } \\
\hline $\mathrm{X}_{1.1}$ & .747 & .000 & Valid \\
\hline $\mathrm{X}_{1.2}$ & .823 & .000 & Valid \\
\hline $\mathrm{X}_{1.3}$ & .749 & .000 & Valid \\
\hline Harga (X2) \\
\hline $\mathrm{X}_{2.1}$ & .762 & .000 & Valid \\
\hline $\mathrm{X}_{2.2}$ & .827 & .000 & Valid \\
\hline $\mathrm{X}_{2.3}$ & .728 & .000 & Valid \\
\hline Kemasan $(\mathrm{X} 3)$ & .752 & .000 & Valid \\
\hline $\mathrm{X}_{3.1}$ & .740 & .000 & Valid \\
\hline $\mathrm{X}_{3.2}$ & .797 & .000 & Valid \\
\hline $\mathrm{X}_{3.3}$ & \multicolumn{5}{|l}{} \\
\hline Keputusan Pembelian $(\mathrm{Y})$ & .000 & Valid \\
\hline $\mathrm{Y}_{1}$ & .807 & .000 & Valid \\
\hline $\mathrm{Y}_{2}$ & .730 & .000 & Valid \\
\hline $\mathrm{Y}_{3}$ & .667 & .000 & Valid \\
\hline $\mathrm{Y}_{4}$ & .729 & \\
\hline
\end{tabular}

Tabel 3 menampilkan hasil dari uji yang telah dilakukan yaitu uji reliabilitas terhadap setiap indikator variabel yang terkandung dalam penelitian ini. Indikator nilai Cronbach Alpha menunjukkan bahwa pernyataan pada ke empat variabel dinyatakan reliabel. Hal ini ditunjukkan dari nilai Cronbach Alpha dari ke empat variabel tersebut memiliki nilai di atas 0,6 yaitu citra merek sebesar 0,663, harga sebesar 0,662, kemasan 0,641, dan keputusan pembelian sebesar 0,709 .
Tabel 3. Uji Reliabilitas

\begin{tabular}{|l|c|c|}
\hline \multicolumn{1}{|c|}{ Variabel } & $\begin{array}{c}\text { Cronbach } \\
\text { Alpha }\end{array}$ & Kesimpulan \\
\hline $\begin{array}{l}\text { Citra Merek } \\
\left(\mathrm{X}_{1}\right)\end{array}$ & .663 & Reliable \\
\hline Harga $\left(\mathrm{X}_{2}\right)$ & .662 & Reliable \\
\hline $\begin{array}{l}\text { Kemasan } \\
(\mathrm{X} 3)\end{array}$ & .641 & Reliable \\
\hline $\begin{array}{l}\text { Keputusan } \\
\text { Pembelian } \\
(\mathrm{Y})\end{array}$ & .709 & Reliable \\
\hline
\end{tabular}

\section{Uji Regresi}

Dari hasil persamaan regresi dalam tabel 4 , dijelaskan bahwa $\mathrm{Y}=0,546+0,321 \mathrm{X} 1+0,284$ $\mathrm{X} 2+0,284 \mathrm{X} 3)$. Penjelasannya adalah :

a. Koefisien regresi yang didapatkan dari variabel citra merek menunjukkan indikator nilai yang positif yaitu 0,321 . Artinya adalah bahwa setiap kenaikan 1 satuan variabel citra merek akan meningkatkan keputusan pembelian sebesar 0,321 satuan.

b. Koefisien regresi yang didapatkan dari variabel harga yaitu 0,284 menunjukkan indikator nilai yang positif. Artinya adalah setiap kenaikan 1 satuan variabel akan berpengaruh meningkatkan keputusan pembelian sebesar 0,284 satuan. 
Tabel 4. Hasil Uji Regresi

\begin{tabular}{|c|c|c|c|c|c|}
\hline \multirow[b]{2}{*}{ Model } & \multicolumn{2}{|c|}{$\begin{array}{l}\text { Unstandardi } \\
\text { zed } \\
\text { Coefficients }\end{array}$} & \multirow{2}{*}{$\begin{array}{c}\begin{array}{c}\text { Standardi } \\
\text { zed } \\
\text { Coefficien } \\
\text { ts }\end{array} \\
\text { Beta }\end{array}$} & \multirow[b]{2}{*}{$\mathrm{t}$} & \multirow[b]{2}{*}{$\begin{array}{l}\text { Si } \\
\text { g. }\end{array}$} \\
\hline & $B$ & $\begin{array}{l}\text { Std. } \\
\text { Error }\end{array}$ & & & \\
\hline $\begin{array}{l}1 \text { (Consta } \\
\text { nt) }\end{array}$ & .546 & .340 & & $\begin{array}{r}1.6 \\
03\end{array}$ & $\begin{array}{r}.11 \\
8\end{array}$ \\
\hline $\begin{array}{l}\text { Citra } \\
\text { Merek } \\
(x 1)\end{array}$ & .321 & .122 & .348 & $\begin{array}{r}2.6 \\
40\end{array}$ & $\begin{array}{r}.01 \\
2\end{array}$ \\
\hline $\begin{array}{l}\text { Harga } \\
(x 2)\end{array}$ & .284 & .101 & .334 & $\begin{array}{r}2.8 \\
17\end{array}$ & $\begin{array}{r}.00 \\
8\end{array}$ \\
\hline $\begin{array}{l}\text { Kemas } \\
\text { an (x3) }\end{array}$ & .284 & .108 & .305 & $\begin{array}{r}2.6 \\
33\end{array}$ & $\begin{array}{r}.01 \\
2\end{array}$ \\
\hline
\end{tabular}

c. Koefisien regresi yang didapatkan dari variabel kemasan yaitu 0,284 menunjukkan indikator nilai yang positif. Artinya adalah setiap kenaikan 1 satuan variabel akan berpengaruh meningkatkan keputusan pembelian sebesar 0,284 satuan

\section{Uji F}

Hasil uji $\mathrm{F}$ berdasarkan Tabel 5 menunjukan nilai signifikansi yaitu yang bernilai 0.000 dan diketahui lebih kecil dari $0,05($ sig < 0,05$)$. Dengan demikiann dapat disimpulkan bahwa uji model pada penelitian ini layak digunakan.

\section{Uji t}

Hasil uji $\mathrm{t}$ dapat dilihat pada Tabel 4 nilai signifikansi dari variabel-variabel bebas yang terdapat pada penelitian ini. Besaran
Tabel 5. Hasil Uji F

\begin{tabular}{|l|l|l|}
\hline Model & F & Sig. \\
\hline Regression & 42.504 & .000 \\
\hline
\end{tabular}

Tabel 6 . Hasil Uji Koefisien Korelasi (R) dan Koefisien Determinasi $\left(\mathbf{R}^{2}\right)$

\begin{tabular}{|c|c|c|c|c|c|}
\hline $\begin{array}{c}\text { Mode } \\
\mid\end{array}$ & $\mathrm{R}$ & $\begin{array}{c}\text { R } \\
\text { Squar } \\
\text { e }\end{array}$ & $\begin{array}{c}\text { Adjuste } \\
\text { d R } \\
\text { Square }\end{array}$ & $\begin{array}{l}\text { Std. } \\
\text { Error of } \\
\text { the } \\
\text { Estimat } \\
\text { e }\end{array}$ & $\begin{array}{c}\text { Durbin } \\
- \\
\text { Watso } \\
n\end{array}$ \\
\hline 1 & $\begin{array}{r}.883 \\
a\end{array}$ & .780 & .761 & .23223 & 2.299 \\
\hline
\end{tabular}

a. Predictors: (Constant), Kemasan ( $\times 3)$, Harga (x2), Citra Merek (x1)

b. Dependent Variable: Keputusan Pembelian (y)

nilai signifikansi dari setiap variabel adalah citra merek $\left(\mathrm{X}_{1}\right)$ memiliki nilai sebesar 0,012, sedangkan variabel kedua yaitu harga $\left(\mathrm{X}_{2}\right)$ sebesar 0,008, yang terakhir variabel kemasan $\left(\mathrm{X}_{3}\right)$ memiliki nilai sebesar 0,012. Sehingga dapat dikatakan bahwa semua variabel-variabel bebas yang terdapat dalam penelitian ini berpengaruh terhadap variabel terikat yaitu keputusan pembelian (Y) karena nilai signifikansinya kurang dari 0,05 .

\section{Uji Koefisien Korelasi (R) dan Koefisien}

\section{Determinasi $\left(\mathbf{R}^{2}\right)$}

Berdasarkan pada Tabel 6, nilai koefisien korelasi pada penelitian ini dapat kita lihat yaitu sebesar 0,883 . Dengan demikian, variabel bebas pada penelitian ini memiliki tingkat keeratan antar variabel terikat yang tinggi. Untuk koefisien 
determinasi diperoleh nilai sebesar 0,780 yang artinya model regresi ini dapat menerangkan variabel terikat sebesar $78 \%$ yang dipengaruhi oleh variabel - variabel bebas yang terdapat pada penelitian ini, sedangkan untuk sisanya $22 \%$ adalah variabel - variabel lain yang tidak terdapat pada penelitian ini.

\section{Uji Asumsi Klasik}

Hasil uji normalitas pada Tabel 7 menunjukan nilai signifikansi dari uji normalitas dapat kita lihat bernilai sebesar 0,089. Nilai tersebut lebih besar dari 0,05 yang artinya data penelitian dikatakan berdistribusi dengan normal.

Pada hasil uji multikolinieritas di Tabel 8, masing-masing variabel bebas memiliki nilai VIF yang lebih kecil dari angka 10 dan nilai toleransi yang berada di angka lebih dari 0,1. Maka dapat dikatakan pada penelitian ini tidak terjadi gejala multikolinearitas.

Hasil uji autokorelasi menyatakan bahwa pada Tabel 9 nilai DW atau DurbinWatson diketahui memiliki nilai sebesar 2.299 dan dengan nilai dU dan 4-dU 1.6589 dan $2.3411(\mathrm{dU}<\mathrm{DW}<4-\mathrm{dU})$. Dengan demikian, Ho diterima karena nilai
Tabel 7. Hasil Uji Normalitas

\begin{tabular}{|l|c|}
\hline & $\begin{array}{c}\text { Unstandarized } \\
\text { Residual }\end{array}$ \\
\hline Kolmogorov-Smirnov Z & .089 \\
\hline Asymp. Sig. (2-tailed) & .200 \\
\hline
\end{tabular}

Tabel 8. Hasil Uji Multikolinieritas

\begin{tabular}{|l|c|c|l|}
\hline \multirow{2}{*}{$\begin{array}{c}\text { Variabel } \\
\text { Independen }\end{array}$} & \multicolumn{2}{|c|}{$\begin{array}{c}\text { Collinearity } \\
\text { Statistics }\end{array}$} & \multirow{2}{*}{ Kesimpulan } \\
\cline { 2 - 3 } & Tolerance & VIF & \\
\hline Citra Merek & .351 & 2.849 & $\begin{array}{l}\text { Tidak terjadi } \\
\text { multikolinieritas }\end{array}$ \\
\hline Harga & .435 & 2.300 & $\begin{array}{l}\text { Tidak terjadi } \\
\text { multikolinieritas }\end{array}$ \\
\hline Kemasan & .457 & 2.190 & $\begin{array}{l}\text { Tidak terjadi } \\
\text { multikolinieritas }\end{array}$ \\
\hline
\end{tabular}

Tabel 9. Uji Autokorelasi

\begin{tabular}{|c|c|l|l|}
\hline DU & 4-DU & $\begin{array}{l}\text { Durbin- } \\
\text { Watson }\end{array}$ & \multicolumn{1}{|c|}{ Kesimpulan } \\
\hline 1.6589 & 2.3411 & 2.299 & $\begin{array}{l}\text { Tidak terjadi } \\
\text { autokorelasi }\end{array}$ \\
\hline
\end{tabular}

indikator DW terdapat di antara dU dan 4-dU. Artinya pada penelitian ini tidak terjadi autokorelasi.

Hasil uji heteroskedastisitas menyatakan bahwa nilai signifikansi variabel yang ada dalam penelitian memiliki nilai yang lebih besar dari $0,05($ sig $>0,05)$ yaitu citra merek memiliki nilai sebesar 0,454, harga dengan nilai sebesar 0,480, dan nilai sebesar 0,512 untuk variabel kemasan. Sehingga dapat dikatakan bahwa pada penelitian ini tidak terjadi heteroskedastisitas.

Hasil uji linearitas menyatakan bahwa ketiga variabel bebas yaitu citra merek, harga, dan kemasan memiliki nilai signifikansi 0,000. 
Tabel 10. Hasil Uji Heteroskedastisitas

\begin{tabular}{|l|l|l|}
\hline Model & Sig. & Kesimpulan \\
\hline (Constant) & .903 & terjadi \\
\hline Citra Merek & .454 & $\begin{array}{l}\text { Tidak } \\
\text { heteroskedastisitas }\end{array}$ \\
\hline Harga & .480 & $\begin{array}{l}\text { Tidak terjadi } \\
\text { heteroskedastisitas }\end{array}$ \\
\hline Kemasan & .512 & $\begin{array}{l}\text { Tidak terjadi } \\
\text { heteroskedastisitas }\end{array}$ \\
\hline \multicolumn{2}{|l}{ a. Dependent Variabel: absres } \\
\hline
\end{tabular}

Tabel 11. Hasil Uji Linearitas

\begin{tabular}{|c|c|c|c|}
\hline 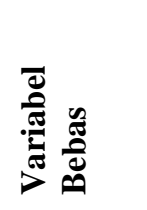 & 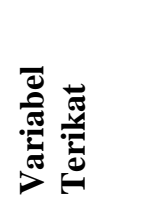 & 离施 & 氞 \\
\hline $\begin{array}{l}\text { Citra } \\
\text { Merek } \\
\text { (X1) } \\
\end{array}$ & \multirow[t]{3}{*}{$\begin{array}{l}\text { Keputusan } \\
\text { Pembelian } \\
\text { (Y) }\end{array}$} & .000 & $\begin{array}{l}\text { Berhubungan } \\
\text { linier }\end{array}$ \\
\hline $\begin{array}{l}\text { Harga } \\
\left(\mathrm{X}_{2}\right)\end{array}$ & & .000 & $\begin{array}{l}\text { Berhubungan } \\
\text { linier }\end{array}$ \\
\hline $\begin{array}{l}\text { Kemasan } \\
\text { (X3) }\end{array}$ & & .000 & $\begin{array}{l}\text { Berhubungan } \\
\text { linier }\end{array}$ \\
\hline
\end{tabular}

Dengan kata lain, dapat dinyatakan bahwa

ketiga variabel bebas tersebut berhubungan linear terhadap variabel terikatnya yaitu keputusan pembelian karena keseluruhan variabel bebas pada penelitian ini memiliki nilai signifikansi kurang dari 0,05 .

\section{KESIMPULAN DAN SARAN}

\section{Kesimpulan}

Dari hasil yang diperoleh dalam penelitian ini, dapat disimpulkan bahwa citra merek, harga, dan kemasan berpengaruh signifikan terhadap keputusan pembelian konsumen.

\section{Keterbatasan dan Saran}

Sampel penelitian hanya menggunakan perusahaan Nexfood pada industri makanan dan minuman dengan menggunakan metode purposive sampling, sehingga hasil penelitian tidak dapat digeneralisasi secara luas untuk setiap perusahaan di Indonesia. Penelitian selanjutnya diharapkan bisa menggunakan semua sektor dan menambah tahun pengamatan. 


\section{DAFTAR PUSTAKA}

Kotler, P., \& Armstrong, G, (2015). Principle Of Marketing, 15th edition. New Jersey : Pearson Prentice Hall.

Kotler, P., and Keller, K, L. (2016) Marketing Management, 15th edition. New Jersey: Pearson Pretice Hall, Inc.

Monawarah, S. (2017). Pengaruh Merek, Harga, dan Kualitas Produk Terhadap Keputusan Pembelian Minuman Teh 2 Daun di Plaza Mulia Samarinda. eJournal Administrasi bisnis, 205-216.

Resmi, N., dan Wismiarsi, T. (2015) Pengaruh Kemasan dan Harga pada Keputusan Pembelian Minuman Isotonik. Jurnal Manajemen dan bisnis Sriwijaya Vol 13. No. 1, 1-20.

Rohmah, S. (2015). Pengaruh Citra Merek, Kualitas Produk, dan Layanan Terhadap Keputusan Pembelian Produk Perhiasan. Jurnal Ilmu dan Riset Manajemen Vol 4, No. 5, 1-15

Setiawati, M., dan Lumbantobing, R. (2017). Pengaruh Promosi dan Kemasan Terhadap Keputusan Pembelian Produk Chitato yang dimediasi Oleh Brand Awareness. Jurnal Manajemen Bisnis Vol 12, No 1,75-88.

Sholicah, I (2015) Hubungan Citra Merek IM3 dengan Minat Beli Konsumen. UIN Sunan Ampel Surabaya.

Sugiyono (2014). Metode Penelitian Managemen. Bandung: Alfabeta

Sugiyono (2012). Metode Penelitian Bisnis. Bandung: Alfabeta

Tjiptono, F. (2014). Pemasaran Jasa-Prinsip, Penerapan dan Penelitian. Yogyakarta: CV. ANDI.

Tunis, A.J., dan Martina S. (2016). Pengaruh Kualitas Produk dan Harga Terhadap Keputusan Pembelian Teh Siap Minum dalam Kemasan. Majalah Ilmiah UPI YPTK vol 22. No. 1, $34-41$.

Yustiawan, O. (2016). Pengaruh Kualitas Produk, Harga, dan Citra Merek Terhadap Keputusan Pembelian Honda Vario. Jurnal Ilmu dan Riset Manajemen Vol 5, No. 2, 1 -20. 


\section{LAMPIRAN}

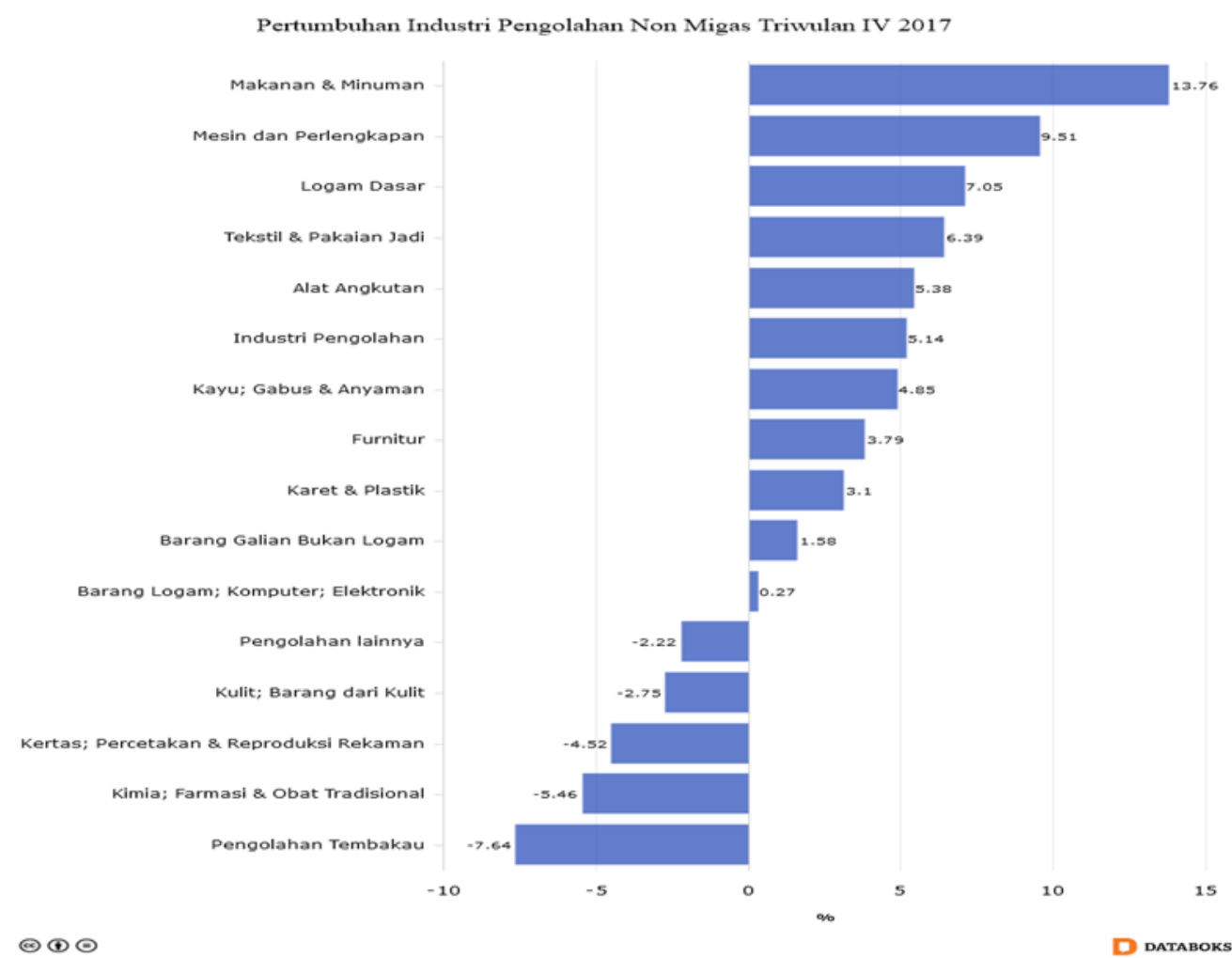

Sumber : Databoks, diolah dari Badan Pusat Statistik (BPS)

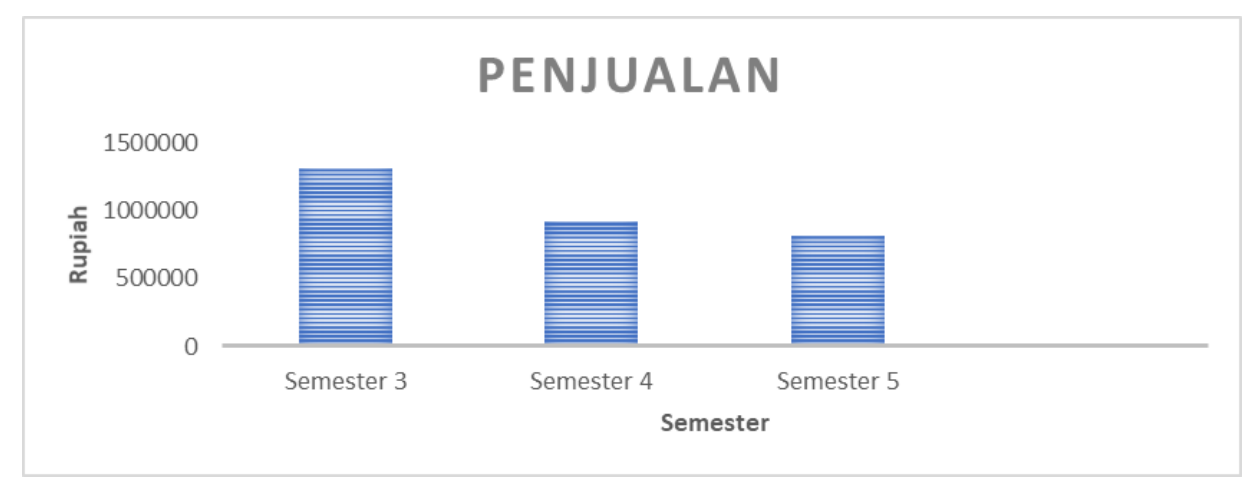

Sumber : Data Internal

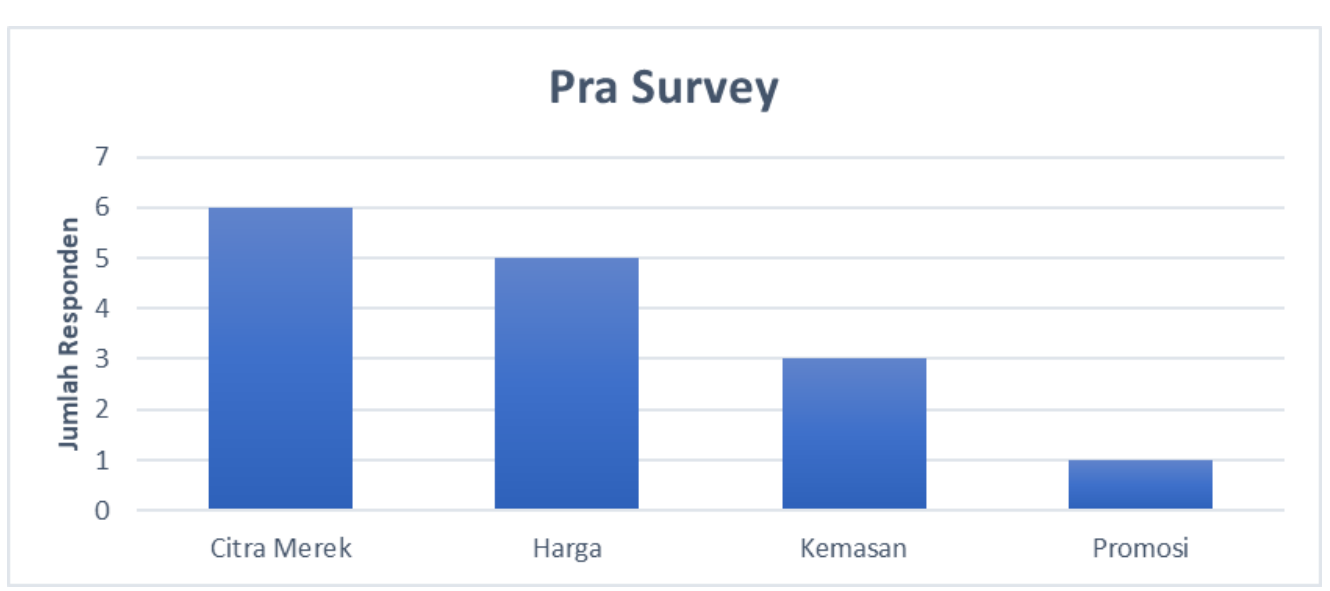

Sumber : Data pengolahan peneliti 